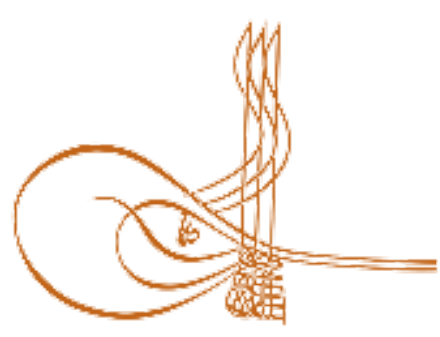

www.turkishstudies.net/education
Turkish Studies - Educational Sciences

eISSN: 2667-5609

Research Article / Araștırma Makalesi

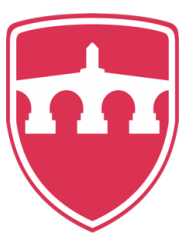

INTERNATIONAL BALKAN

UNIVERSITY

Sponsored by IBU

\title{
Okul Psikolojik Danışmanlarının Gözünden Sosyal Medya, Siber Zorbalık ve Bilgisayar Oyunları ile İlgili Nitel Bir Çalışma
}

\author{
Social Media, Cyber Bullying and Computer Games Problems in Counseling Process
}

\author{
Ferahim Yeşilyurt*
}

\begin{abstract}
Today, the Internet captivates users of all ages becoming widespread. Several problems start to arise with the increasing usage of the internet. School psychological counselors were interviewed in this research with the aim of investigating what kind of problems that psychological counselors experience with students in relation to internet. The phenomenological tradition of qualitative research was chosen for this study. Semi-structured interviews were conducted. The interview involved five open ended questions. Psychological counselors answered which problems they experience related to internet in the school, what they surprise, what they learn from students, their works and study, the need of training about this and their expectations from training. 25 psychological counselors working in İstanbul were participated in this study. Results indicated that psychological counselors experience the feeling of incompetence regarding problems with internet and they need in-service training. Psychological counselors need in-service training with respect to social media and computer games. It was determined that psychological counselors need more in-service training intended for practical information than theoretical information. It was suggested that the authoritios of the Ministry of Education should prepare in-service training plans especially regarding the use of social media and computer games in order to meet the needs of information related to the internet. Also, it was suggested that the content of in-service training should be works intended for practical information as much as possible. It will be beneficial for psychological counselors to do group guidance activities related to cyber bullying, social media addiction, computer games intended for students in order them to develop time management skills.
\end{abstract}

Structured Abstract: Introduction There are more than 16 million students studying in Turkish primary and secondary schools only (Infografik, 2019). Behaviour difficulties are experienced by $11 \%$ of these children and teenagers (Turkish Ministry of Health, 2011). Based on these figures, we can say that we face is an important problem. In schools, counselling services to help students at schools are provided by the school psychologists. These psychologists have an important role in helping students in their work at school and also referring them to relevant organisations where necessary. However, these psychologists' training during their

Bu araştırmanın bir bölümü 19 - 22 Haziran 2019 tarihleri arasında düzenlenen VIIth International Eurasian Educational

Research Congress/ 7. Uluslararası Avrasya Eğitim Araștırmaları Kongresi’nde sunulmuștur.

* * Dr. Öğr. Üyesi, Fatih Sultan Mehmet Vakıf Üniversitesi, Eğitim Fakültesi, Rehberlik ve Psikolojik Danışmanlık.

Asst. Prof., FSM Foundation University, Faculty of Education, Psychological Counselling and Guidance.

ORCID 0000-0003-2490-2685

fyesilyurt@fsm.edu.tr

Cite as/ Atıf: Yeşilyurt, F. (2020). Makale başlı̆̆ı, Turkish Studies - Education, 15(2), 1349-1365. https://dx.doi.org/10.29228/TurkishStudies.40070

Received/Geliş: 09 December/Aralık 2019

Accepted/Kabul: 24 April/Nisan 2020

Copyright (C) INTAC LTD, Turkey 
undergraduate studies are not focussed enough on practical work. Their supervising lecturers are not equipped enough on these either (Ozyurek, 2009). Accordingly, school psychologists are experiencing serious problems in terms of providing psychological help to students. As the internet has become widely used in recent years, these psychologists are facing new problems. As a result of the new problems coming up, there have been a lot of research studies carried out on the effects of internet on children and teenagers. However, there is no single study carried out yet about the effects of students' internet experiences on their school environments. For that reason, to understand what type of problems they face on the internet and how the problems and experiences are reflected in schools, school psychologists have an important role.

To identify the issues that students face and, at the same time, to understand the competencies of the psychologists about internet related issues are important for two reasons: Identification of the problems students face. Identification of the training needs of school psychologists. Not feeling competent in the areas they work would likely to increase their frustrations (Aslan, 2018)

Some existing study provides a deep research on the internet problems and experiences faced by school psychologists in terms of social media, cyber-bullying and computer games during counselling sessions. It is predicted that this study will give a different practical point of view for the Turkish Ministry of Education authorities. The purpose of this study is to examine the experiences of school psychologists during counselling sessions regarding the use of social media, cyber-bullying and computer games. For this reason, the study will seek to answer the questions below:

1) How are the school psychologists experiencing social media, cyber-bullying and computer games related issues in their counselling sessions at schools?

2) What are they doing about these issues?

3) In which areas do they need help with training?

4) What do they expect from any future training sessions?

\section{Methodology}

As the purpose of this study is to find out about the school experiences of school psychologists during counselling sessions regarding social media, cyber-bullying and computer games, the Phenomenology method was used for this study. The study group consists of 25 school psychologists working in primary and secondary schools in Turkey. When selecting the participants in the study, purposeful sampling and snowball sampling were used. To examine the views and experiences of the participants, they were interviewed. The details obtained after interviewing the participants were put in a report and then content analysis was made.

\section{Findings, Discussions and Suggestions}

In this study where the problems experienced by school psychologists regarding internet usage, it has been noted that the psychologists frequently faced issues about social media and computer addiction and cyber-bullying, and that they had to learn games in different styles. It was observed that the school psychologists were mainly organising informative seminars for students and parents, and that group counselling sessions were rarely used.

In addition, it has been concluded that the school psychologists were not feeling competent enough to deal with internet related problems and that they would require special internal training sessions to deal with social media, computer games and cyber-bullying related problems. However, their training should be practical and focus on technology. A review of previous studies was conducted and it has been decided that those previous studies about internet had mainly focussed on children and teenagers rather than school psychologists. For that reason, this study is important as it was conducted from the perspective of school psychologists.

It has been decided that the Turkish Ministry of Education authorities should prepare internet related training sessions to meet the needs of school psychologists, especially about the use of social media and computer games and that the training sessions should predominantly focus on the practical aspects. To bette use their time, it was suggested that school psychologists should use group counselling sessions with children.

Turkish Studies - Education, 15(2) 
Keywords: Education, Psychological Consultants, Cyber Bullying, Social Media, Game Addiction, Computer Games.

Öz: İnternet günümüzde hızla yaygınlaşarak her yaştan kullanıcıyı kendisine çekmektedir. Artan kullanımla birlikte bazı sorunlar da ortaya çıkmaya başlamıştır. Psikolojik danışmanların okul ortamında öğrencilerle internetle ilişkili olarak ne tür sorunlarla karşılaştıklarını belirlemek amacıyla yapılan bu araştırmada okul psikolojik danışmanlarıyla görüşülmüştür. Araştırmada Nitel araştırma yöntemlerinden Fenomenoloji yaklaşımı tercih edilmiştir. 2018 yılında yarı yapılandırılmış görüşme yöntemiyle veriler toplanmıştır. Görüşmede beş açık uçlu soru sorulmuştur. Psikolojik danışmanlara; okulda internet ile bağlantılı hangi sorunlarla karşılaştıkları, nelere şaşırdıkları, öğrencilerden neler öğrendikleri, yaptıkları çalışmalar, bu konuda eğitim ihtiyacı ve eğitimden beklentileri ile ilgili sorular sorulmuştur. Çalışmada amaçlı örnekleme yöntemiyle İstanbul ilinde görev yapan yirmi beş psikolojik danışmana ulaşılmıştır. Elde edilen bulgular 1şığında psikolojik danışmanların internetle ilgili sorunlarda kendilerini yeterli hissetmedikleri ve hizmet içi eğitime ihtiyaç duydukları bulunmuştur. Psikolojik danışmanlar sosyal medya ve bilgisayar oyunları konusunda hizmet içi eğitime ihtiyaç duymaktadırlar. Hizmet içi eğitimde kuramsal bilgilerden çok uygulamaya dönük eğitimlere ihtiyaç duydukları saptanmıştır. Milli Eğitim Bakanlığı yetkilileri psikolojik danışmanların internetle ilgili konularda bilgi ihtiyacını karşılamaya yönelik özellikle sosyal medya kullanımı ve bilgisayar oyunları konularında hizmet içi eğitim planları hazırlamaları ve bu eğitimlerin içeriğinin mümkün olduğunca uygulamaya yönelik çalışmalar olması önerilmektedir. Psikolojik danışmanların zamanlarını daha etkili kullanmaları açısından öğrencilere yönelik bilgisayar oyunları, sosyal medya bağımlılı̆̆ı ve siber zorbalık konularıyla ilgili grup rehberliği etkinlikleri yapmaları faydalı olacaktır.

Anahtar Kelimeler: Eğitim, Psikolojik Danışman, Siber Zorbalık, Sosyal Medya, Oyun Bağımlılı̆̆ı, Bilgisayar Oyunları.

\section{Giriş}

Türkiye'de sadece ilköğretim ve lise düzeyinde on altı milyondan fazla öğrenci bulunmaktadır (İnfografik, 2019). Çocuk ve ergenlerdeki sorunlu davranış oranı \%11'dir (Sağlik Bakanlığ1, 2011). Buna göre önemli bir sorunla karşı karşıya olunduğu söylenebilir. Okul ortamında öğrencilere destek olması beklenen ruh sağlığı hizmeti okul psikolojik danışmanları tarafından sağlanmaktadır. Psikolojik danışmanlar öğrencilerin gerek okulda yapılacak çalışmalarla gerekse uygun yardımı alabilecekleri kurumlara yönlendirilmesinde önemli role sahiptirler. Ancak psikolojik danışmanların lisans eğitimleri boyunca aldıkları dersler yeterince uygulamaya dönük verilmemekte dahası süpervizyon veren öğretim üyelerinin de yeterli donanıma sahip olmadıkları görülmektedir (Özyürek, 2009). Bu doğrultuda okullarda çalışan psikolojik danışmanlar çok geniş bir yelpazede öğrencilerin ruhsal sorunlarına uygun yardım hizmetini sağlama konusunda ciddi sorunlar yaşamaktadırlar. Son zamanlarda ise internetin yaygınlaşmasıyla birlikte internetle bağlantılı olan yeni sorunlarla karşı karşıya kalmıştırlar.

Günümüzde gerçek yaşamdan sağlanan birçok fayda artık internet üzerinden sağlanmaktadır. Gıdadan giyime, ulaşımdan bankacılığa, sinemadan oyun ve eğlenceye kadar bu etkinlikleri görmek mümkündür. İnternet aynı zamanda fiziksel ve zihinsel sınırları ortadan kaldırarak mesafeleri kısaltmaya başlamıştır. Hatta psikolojik danışmanlık ve rehberlik hizmetinin bile internet üzerinden verilmesiyle ilgili çalışmalar yapılmaktadır (Hamamcı, 2007; Savaş ve Hamamc1, 2010).

İnternet, ortaya çıktıktan sonra kısa denebilecek bir sürede neredeyse dünyanın her bölgesine yayılmıştır. Dünyadaki yaygınlaşmaya paralel olarak Türkiye'de de internet yaygınlığı artmıştır. Türkiye'de 2004 yılında internet kullanım oranı \%18,8 iken, 2010 yılında \%41,6, 2016 yılında ise \%61,2'ye ulaşmıştır (TUİK, 2016).

İnternet kullanımı her yaş grubundan büyük bir talep görerek hızla yaygınlaşmakla birlikte, çocuk ve ergenler tarafından çok daha fazla ilgigörmektedir (Ceyhan, 2008). Özellikle ergenler 
değişim döneminde oldukları için her türlü yeniliğe karşı son derece açıktırlar. Buna paralel olarak ortaya çıkan endişeler nedeniyle internetin çocuk ve ergenlerdeki etkieri üzerine birçok araştırma yapılmıştır. Yapılan araştırmalarda internet bağımlılı̆̆ı, (Çetinkaya, 2013; Doğan, 2013; Gökçearslan ve Günbatar, 2012; Kayri ve Günüç, 2010; Öztabak, 2018; Taş, 2018), oyun bağımlılığı, (Ayas, 2012; Desai vd. 2010; Peker, 2010; Horzum, 2011; Van Rooij, vd 2011; Yeşilyurt, 2014), siber zorbalık (Arıcak, 2009; Ayas ve Horzum, 2011; Ayas, 2012; Aydoğan, 2009; Erdur-Baker ve Kavşut, 2007; Yaman ve Peker, 2012) gibi konular sıklıkla ele alınmaya başlamıştır.

Siber zorbalık konusunda yapılan çalışmalarda farklı yaygınlık oranları bulunmuştur. Siber zorbalıkla ilgili ilköğretim öğrencileri ile yapılan bir araştırmada öğrencilerin \%18,6'sının sanal zorbalığa maruz kaldığı (Ayas ve Horzum, 2011), İlköğretim ikinci kademede yapılan bir çalışmada da öğrencilerin \%32,6'sının en az bir kez sanal zorbalığa maruz kaldıkları bulunmuştur (Aydoğan, Dilmaç ve Deniz, 2009). Lise öğrencileriyle yapılan diğer bir çalışmada öğrencilerin \%17,4'ünün sanal zorbalığa maruz kaldığı bulunmuştur. Erdur-Baker ve Kavsut (2007) tarafindan yapılan çalışmada sanal kurban oranının ise \%30'a ulaştığ 1 belirlenmiştir. Çalışmalarda farklı yaygınlık oranları bulunmuş olsa da bu çalışmalar siber zorbalık davranışının öğrenciler arasında yaygın olduğunu düşündürmektedir.

İnternet bağımlılığıyla ilgili 12-18 yaş arasındaki ergenler üzerinde yapılan bir çalışmada internet bağımlılığ yaygınlığ $1 \% 12,6$ olarak bulunmuştur (Doğan, 2003). Bir başka çalışmada örneklemin \%8'i sinırlı semptom gösteren, \%1'i ise internet bağımlısı olarak bulunmuştur (Çetinkaya 2013). Lise kademesinde yapılan bir çalışmada ise \%2,3 internet bağımlılığı görülmüştür (Gökçearslan ve Günbatar, 2012). Başka bir çalışmada ise öğrencilerin \%12,6'sının internet bağımlısı olma yolunda risk içerisinde oldukları ve \%12,2'sinin de internet bağımlısı olduğu tespit edilmiştir (Kayri ve Günüç, 2010).

Alanyazı incelendiğinde bilgisayar oyun bağımlılı̆̆ı üzerine de çalışmalar yapıldığ görülmektedir. Araştırma sonuçlarına göre; erkek öğrenciler kız öğrencilere göre daha fazla bilgisayar oyunu oynamaktadır (Horzum, 2011; Yeşilyurt, 2014). Oyun bağımlılı̆̆ının yaygınlığında da farklı oranlar bulunduğu görülmüştür. Yapılan çalışmalarda oyun bağımlılı̆̆ının yaygınlığ \% 4,9 (Desai vd. 2010), \%7,9 (Peker vd. 2010) ve \%3 (Van Roij vd. 2011) olarak bulunmuştur. Ancak öğrencilerin internet üzerinden yaşadıkları olayların ve deneyimlerin okul ortamına nasıl yansıdığının belirlenmesi konusunda çalışmanın yapılmamış olduğu görülmektedir. $\mathrm{Bu}$ nedenle, okullarda görev yapan psikolojik danışmanları internet üzerinden okullara yansıyan ne tür problemlerle karşılaştıkları, okulda yaşanan sorun ve deneyimlerin ortaya çıkarılması büyük bir önem taşımaktadır. Öğrencilerin yaşadıkları sorunların belirlenmesi ve aynı zamanda psikolojik danışmanların da internet konusundaki yeterliliklerinin saptanması iki açıdan önem taşımaktadır. Birincisi, öğrencilerin sorunları belirlenecek, ikincisi ise; psikolojik danışmanların internet konusuyla ilgili eğitim ihtiyaçları ortaya çıkarılabilecektir. Psikolojik danışmanların çalıştıkları konularda kendilerini yeterli hissetmemeleri yaşayabilecekleri tükenmişlik düzeyini de artıracaktır (Aslan, 2018).

Mevcut araştırma, psikolojik danışmaların internetle bağlantılı olarak psikolojik danışma sürecinde karşılaştıkları sosyal medya, siber zorbalık ve bilgisayar oyunları ile ilgili sorun ve deneyimleri derinlemesine yansıtan özgün bir araştırma özelliği taşımakta ve bu nedenle araştırma sonucunun okul yöneticilerinin öğretmenlere psikolojik danışmanlara ve Milli Eğitim Bakanlığ yetkililerine uygulama odaklı bir bakış açısı sağlayacağı düşünülmektedir. Bu çalışmanın amacı, psikolojik danışmanların psikolojik danışma sürecinde karşılaştıkları sosyal medya, siberzorbalık ve bilgisayar oyunlarıyla ilgili deneyimlerin derinlemesine incelenmesidir. Bu bağlamda aşağıdaki sorulara yanıt aranmıştır:

1. Psikolojik danışmanların okullarda yaptıkları danışmanlık görüşmelerinde sosyal medya, siberzorbalık ve bilgisayar oyunlarıyla ilgili deneyimleri nasıl gerçekleşmektedir? 
2. Bu bağlamda hangi çalışmaları yapmaktadırlar?

3. Hangi alanlarda eğitim ihtiyacı hissetmektedirler?

4. Yapılacak eğitimlerden nasıl bir beklenti içindedirler?

\section{Yöntem}

\section{Araştırma Deseni}

$\mathrm{Bu}$ araştırma psikolojik danışmanların danışma sürecinde karşılaştıkları sosyal medya, siber zorbalık ve bilgisayar oyunlarıyla ilgili okuldaki deneyimlerini ortaya çıkarmayı amaçladığı için nitel araştırma yaklaşımlarından Fenomenoloji yaklaşımı tercih edilmiştir. Nitel araştırmalar insanların deneyimlerini nasıl yorumladıklarıyla ve deneyimlerine ne gibi anlamlar yükledikleriyle ilgilenirler (Merriam, 2013). Bu bağlamda konu ile ilgili literatürde yeterli bilgi birikimine ulaşılamamış olduğu için nicel araştırma yerine derinlemesine bir keşif çalışması sunan nitel araştırma tercih edilmesi önerilmektedir (Patton,2002). Bu doğrultuda bireyin deneyimlerine ve olguya ilişkin anlamlandırmalarına odaklanan (Creswell, 2014) fenomenololik yaklaşımdan yararlanılmıştır. Bu çalışmada incelenen fenomen ise psikolojik danışman olmak ve öğrencilerle sosyal medya, siberzorbalık ve bilgisayar oyunları konusunda danışmanlık yapmak ve buna dair deneyimlerdir. $\mathrm{Bu}$ bağlamda psikolojik danışmanların danışmanlık sürecinde karşılaştıkları internetle ilişkili olgulara yönelik deneyimleri incelenerek karşılaştıkları durumlar, yardım hizmetleri ve eğitim ihtiyaçlarına dair bilgi edinmek amaçlanmaktadır.

\section{Çalışma Grubu}

Araştırmanın çalışma grubunu ilköğretim birinci kademe, ilköğretim ikinci kademe ve lise kademelerindeki okullarda görev yapan yirmi beş psikolojik danışman oluşturmaktadır. Katılımcıların belirlenmesinde amaçlı örnekleme ve kartopu örnekleme yöntemleri kullanılmıştır. Çalışma grubu oluşturulurken amaçlı örnekleme yöntemlerinden ölçüt örnekleme yöntemine uygun biçimde belirlenmiştir. Araştırmada birinci ölçüt ilköğretim ve lise düzeyinde çalışan bir psikolojik danışman olmaktır. İkinci ölçüt ise psikolojik danışmanlık seanslarında internetle bağlantılı olan sosyal medya, siberzorbalık ve bilgisayar oyunları konusunda deneyime sahip olmak olarak belirlenmiştir. Kartopu örnekleme tekniği ile de örnekleme ölçütüne uyan katılımcılar belirlenmiş ve aday katılımcılar gönüllülük ilkesi çerçevesinde çalışmaya davet edilmiştir. Çalışma bağlam açısından bir keşif çalışması niteliğinde olduğu için ilköğretim kademeleri ve lise kademesinden psikolojik danışmanların seçilmesine çalışılmıştır. Bu doğrultuda kapsam geniş tutulmuştur. Katılımcıların demografik özelliklerine ilişkin bilgiler Tablo 1'de yer almaktadır.

Tablo 1: Tablo Katılımcıların Demografik Özellikleri

\begin{tabular}{|c|c|c|c|c|c|}
\hline NO & YAŞ & KATILIMCILAR & KIDEM & KADEME & OKUL TÜRU் \\
\hline 1 & 25 & Rahşan & 5 & Lise & Özel Okul \\
\hline 2 & 24 & Candan & 2 & $\begin{array}{l}\text { İlköğretim } 2 . \\
\text { kademe }\end{array}$ & Özel Okul \\
\hline 3 & 35 & Metin & 9 & $\begin{array}{l}\text { İlköğretim } 2 . \\
\text { kademe }\end{array}$ & Resmi Okul \\
\hline 4 & 26 & Fatma & 3 & $\begin{array}{l}\text { İlköğretim } 2 . \\
\text { kademe }\end{array}$ & Resmi Okul \\
\hline 5 & 25 & Sümeyye & 6 & $\begin{array}{l}\text { İlköğretim } 1 . \\
\text { kademe }\end{array}$ & Resmi Okul \\
\hline 6 & 30 & Hüseyin & 5 & $\begin{array}{l}\text { İlköğretim } 1 . \\
\text { kademe }\end{array}$ & Özel Okul \\
\hline
\end{tabular}




\begin{tabular}{|c|c|c|c|c|c|}
\hline 7 & 27 & Zeynep & 6 & $\begin{array}{l}\text { İlköğretim } 2 . \\
\text { kademe }\end{array}$ & Resmi Okul \\
\hline 8 & 28 & İrfan & 7 & $\begin{array}{l}\text { İlköğretim } 2 . \\
\text { kademe }\end{array}$ & Resmi Okul \\
\hline 9 & 28 & Ali & 5 & Lise & Özel Okul \\
\hline 10 & 28 & Asli & 6 & $\begin{array}{l}\text { İlköğretim } 1 . \\
\text { kademe }\end{array}$ & Özel Okul \\
\hline 11 & 39 & Hümeyra & 13 & Lise & Resmi Okul \\
\hline 12 & 26 & Hasan & 6 & Lise & Resmi Okul \\
\hline 13 & 34 & Meryem & 8 & $\begin{array}{l}\text { İlköğretim } 2 . \\
\text { kademe }\end{array}$ & Resmi Okul \\
\hline 14 & 28 & Mehtap & 6 & $\begin{array}{l}\text { İlköğretim } 2 . \\
\text { kademe }\end{array}$ & Resmi Okul \\
\hline 15 & 53 & Habibe & 30 & Lise & Özel Okul \\
\hline 16 & 22 & Gamze & 1 & $\begin{array}{l}\text { İlköğretim } 2 . \\
\text { kademe }\end{array}$ & Özel Okul \\
\hline 17 & 24 & Asiye & 1 & $\begin{array}{l}\text { İlköğretim } 1 . \\
\text { kademe }\end{array}$ & Resmi Okul \\
\hline 18 & 46 & Meltem & 20 & $\begin{array}{l}\text { İlköğretim } 2 . \\
\text { kademe }\end{array}$ & Özel Okul \\
\hline 19 & 30 & Erkin & 8 & $\begin{array}{l}\text { İlköğretim } 2 . \\
\text { kademe }\end{array}$ & Resmi Okul \\
\hline 20 & 34 & Büşra & 8 & $\begin{array}{l}\text { İlköğretim } 1 . \\
\text { kademe }\end{array}$ & Resmi Okul \\
\hline 21 & 40 & Yasemin & 12 & $\begin{array}{l}\text { İlköğretim } 2 . \\
\text { kademe }\end{array}$ & Resmi Okul \\
\hline 22 & 26 & Elif & 6 & $\begin{array}{l}\text { İlköğretim } 1 . \\
\text { kademe }\end{array}$ & Resmi Okul \\
\hline 23 & 28 & Feyza & 5 & Lise & Resmi Okul \\
\hline 24 & 45 & Irmak & 20 & Lise & Özel Okul \\
\hline 25 & 43 & Elvan & 18 & Lise & Özel Okul \\
\hline
\end{tabular}

Tablo 1'den anlaşılacağı üzere çalışma grubu 6'sı erkek, 19'u kadın olmak üzere 25 psikolojik danışmandan oluşmaktadır. Psikolojik danışmanların yaş ortalaması 31,7 yıldır.

\section{Veri Toplama Aracı}

Katılımcıların söz konusu fenomene ilişkin görüş ve deneyimlerini derinden incelemek için görüşme yönteminden faydalanılmıştır. Katılımcıların bakış açılarını anlamak ve olgulara yükledikleri anlamları belirleyebilmek için görüşme yöntemi faydalı olmaktadır (Berg ve Lune, 2015) . Nitel araştırmalar genellikle bir fenomeni derinlemesine inceleme amacı taşıdığından bu çalışmada görüşme yöntemi tercih edilmiştir. Yarı yapılandırılmış görüşme formu görüşmenin etkileşim ortamına göre araştırmacıya esneklik tanıdığı için tercih edilmiştir. Böylece daha kapsamlı ve derinlemesine bilgilerin elde edilebileceği düşünülmüştür. Çalışmada okullarda görev yapan psikolojik danışmanların gözünden bir bakış açısı sunmak amacıyla görüşme için yarı 
yapılandırılmış bir görüşme formu hazırlanmıştır. Görüşme sorularının hazırlanmasında araştırmacının kişisel gözlemlerinden ve ilgili literatürden yola çıkılmıştır. Uzman görüşü için rehberlik ve psikolojik danışmanlık alanında görev yapan üç akademisyenden yardım istenmiştir. Ardından okulda çalışan iki psikolojik danışmanla pilot uygulama yapılımış ve yarı yapılandırılmış görüşme formuna son şekli verilmiştir.

Görüşmede, katılımcıların psikolojik danışma sürecinde sosyal medya, siber zorbalık ve bilgisayar oyunlarıyla ilgili yaşadıkları deneyimler ve okulda ne tür çalışmalar içinde olduklarını ortaya çıkarmak için beş açık uçlu soru sorulmuştur. Psikolojik danışmanlara, okulda yaptıkları danışma uygulamalarında sosyal medya, siber zorbalık ve bilgisayar oyunlarıyla ilgili hangi sorunlarla karşılaştıkları, öğrencilerden neler öğrendikleri, yaptıkları çalışmalar, bu konuda eğitim ihtiyac1 ve eğitimden beklentileri ile ilgili sorular sorulmuştur. Ortalama yirmi dakika süren görüşmeler erkek araştırmacı tarafından yapılmış ve katılımcıların sözlü onayı alınarak ses kaydı gerçekleştirilmiştir. Görüşmeler okulda sessiz bir ortamda ve yüz yüze yapılmıştır. Her görüşmede sorular aynı sırayla sorulmamış, etkileşimin doğasına uygun olarak esneklik sağlanmıştır. Yeterli veriye ulaşıldığı düşünüldügünde katılımcıların eklemek istedikleri konular sorularak görüşme sonlandırılmıştır.

\section{Veri analizi}

Görüşme sonucunda elde edilen veriler öncelikle yazıya aktarılmış, ardından içerik analizine tabi tutulmuştur. Psikolojik danışmanların ifadeleri kelime kelime analiz edilerek kodlar çıkarılmıştır. Anlam bakımından birbiriyle ilişkili olduğu düşünülen kodlar genel başlıklar haline getirilerek temalar oluşturulmuştur. Analizler için QDA Miner Lite v.2.0.6 (Provalis Research, Montreal, Kanada) yazılımından yararlanılmıştır.

Araştırmanın güvenirliği açısından yapılan görüşmelerde çalışmanın amacı açıklanmış, süre, içerik ve kapsamla ilgili bilgilendirme yapılarak katılımcıların sözel onamları alınmıştır. Ayrıca bulgular katılımcılarla paylaşılarak araştırmacının olası önyargılı yaklaşımını kontrol etmek amacıyla katılımcıların tekrar onayı alınmıştır. Araştırmada katılımcıların kimliğini korumak adına gerçek isimleri kullanılmamış, görüşme yapılan psikolojik danışmanlar için takma isimler kullanılmıştır.

\section{Bulgular}

Analiz sonucunda bulgular iki farklı tema altında toplanmıştır. İlk tema psikolojik danışmanların danışma sürecinde hangi problemlerle karşılaştıkları ve bu konudaki deneyimlerine ilişkindir. İkinci tema psikolojik danışmanların karşılaştıkları sorunlarda neler yaptıkları ve ne tür bir eğitim ihtiyacı içerisinde olduklarına yöneliktir.

\section{Psikolojik danışmanların danışma sürecinde karşılaştıkları sorunlar ve deneyimleri}

$\mathrm{Bu}$ tema altında sosyal medya, sanal zorbalık, bilgisayar oyunları ve kimliklenme süreci olmak üzere dört alt temaya ulaşılmıştır. Sosyal medya alt teması ise WhatsApp, Facebook, Instagram ve YouTube olmak üzere dört ayrı alt tema biçiminde kodlanmıştır. Psikolojik danışmanların okullarda karşılaştıkları durumlara ilişkin görüşlerine göre tablolar oluşturulmuştur (Tablo 2). 
Tablo 2. Psikolojik Danışmanların En Çok Karşıllaştıkları İnternet Temalı Sorunlar

\begin{tabular}{|c|c|c|c|}
\hline $\begin{array}{l}\text { Tema } \\
\text { (Kategoriler) }\end{array}$ & Kodlar & $\mathbf{N}$ & $\%$ \\
\hline \multirow{11}{*}{$\begin{array}{l}\text { Psikolojik } \\
\text { Danışmanların } \\
\text { Karşılaştıkları } \\
\text { Sorunlar ve } \\
\text { Deneyimler }\end{array}$} & Sosyal Medya & & \\
\hline & Instagram & 6 & 24 \\
\hline & WhatsApp & 11 & 44 \\
\hline & Facebook & 3 & 12 \\
\hline & Youtube & 8 & 40 \\
\hline & Bilgisayar oyunları & 17 & 68 \\
\hline & Sanal zorbalık & 8 & 32 \\
\hline & Kimliklenme & & \\
\hline & Popüler youtuberlar & 6 & 24 \\
\hline & Kore dizileri & 1 & 4 \\
\hline & Instagram fenomenleri & 1 & 4 \\
\hline
\end{tabular}

Tablo 2 incelendiğinde, psikolojik danışmanların okullarda internete bağlı en çok bilgisayar oyunları ile bağlantılı sorunlarla karşılaştıkları (\%68) görülmüştür. Bunu \%32 oranında WhatsApp kaynaklı sorunlar izlemektedir.

Çocuklar ve ergenlerin teknolojik cihaz kullanımı ve internete bağlanma oranlarının oldukça yaygın olduğu ve bunların öğrenciler arasında son derece popüler etkinlikler olduğu ifade edilmiştir. Rahşan bu durumu şu şekilde ifade etmektedir:

"öğrencilerle yaptığımız görüşmede telefonsuz hiçbir şey yapmadıkları yemek yerken, ders çalışırken bile her türlü ortamda telefon ve sosyal medya ile iç içe olduklarını aktarıyorlar"

Candan ise;

“öğrencilerimizin birçoğunun sosyal medya bağımlısı olduğunu düşünüyorum. WhatsApp Facebook Instagram hayatlarının merkezi durumunda"

ifadesi ile yoğun sosyal medya kullanımını vurgulamaktadır. Öğrencilerin bir bölümünün ise bilgisayar oyunlarını bir spor aktivitesi olarak kullandıkları görülmektedir. Sümeyye bu duruma oldukça şaşırdığını ifade etmiştir:

"E-spor adı altında bir mesleğin ortaya çıkmıș olması beni oldukça şaşırtıyor. Gelecekte kendini bu mesleğin bir çalışanı olarak görmek isteyen ve bunun için akademik başarıyı bir kenara koyup sadece bu amaç için zamanını internet oyunlarına ayıran çok sayıda öğrencim var"

Bazı öğrenciler günün okul dışındaki kalan önemli bir bölümünü oyun oynayarak geçirmektedirler. $\mathrm{Bu}$ durum psikolojik danışmanların karşısına çıkan önemli bir problem olarak görülmektedir. Zeynep bu durumu şu şekilde özetlemektedir: 
"Bir günün beş ile yedi saat aralığında bir zaman diliminde bilgisayar başında sahip olduğu karakteri geliştirmeye ayıran internet oyun bağımlılığı geliştiren öğrencilerimiz var”

Bazı öğrenciler bilgisayar oyunlarına karşı bağımlılık geliştirebilmekte ya da problemli bir davranış içinde olabilmektedirler.Benzer şekilde siber zorbalık konusu da psikolojik danışmanların yaygın olarak karşılaştıkları önemli bir sorun olarak görülmektedir. Okullardaki siber zorbalıkla ilgili davranışlar ağırlıklı olarak WhatsApp üzerinden gerçekleşmektedir. Fatma bu durumu şu şekilde ifade etmiştir:

“illkokuldan liseye kadar sanal zorbalıkla sıklıkla karşılaşıyoruz. Öğrencilerin WhatsApp üzerinden birbirlerine zorbalık yapması ve sınıf olarak kurulan gruba bir arkadaşlarını almayarak dışlama gibi sorunlar yaşanıyor. Örneğin iki öğrencim okulda olan bir tartışmayı WhatsApp üzerinden sanal olarak devam ettirmişler ve sanal ortamda birbirlerini görmedikleri için daha rahat bir şekilde karşısındaki arkadaşını kırıcı sözler kullanarak aralarındaki olayı daha çözülmez hale getirmeleri gibi bir problem yaşadım. Bu olayın ardında sınıf WhatsApp grubundan atılma ve sınıfta lider olan kişinin diğerlerini arkadaşlarına düşman etme ile devam eden bir süreç yaşanmıştı"

Sanal ortamlar, öğrenciler birbirlerini görmedikleri için çok rahat karşılıklı sözel hakaretler içerebilen ortamlar olarak karşımıza çıkmaktadır. Ancak bu kişiler tekrar yüz yüze aynı ortama geldiklerinde sanalda başlayan problem hızla gerçek yaşama yansımaktadır. Bu durumda okula yansıyan problemi çözme konusunda yine psikolojik danışmanlar görev almak durumunda kalmaktadırlar. Irmak bu durumu şu şekilde ifade etmiştir:

"Bazen sosyal medyada küfür etme sonrası arkadaşlar arasında kavgalar kırgınlıklar oluşabiliyor. Küfürleşme sonrasında farklı gruplar karşı karşıya gelebiliyor. Yine sosyal medyada birbirleri hakkında söylenti yaymak, küfür ve hakaret içeren davranışlar içerisinde bulunmak, sahte hesapla arkadaşlarını taciz etmek gibi arkadaşlı ilişkilerini olumsuz etkileyen durumlarla karşılaştım"

Öğrenciler cep telefonu ve tablet gibi mobil cihazlarla okula gelebildikleri için zaman zaman okulda da siber zorbalık davranışları meydana gelebilmektedir. Mehtap bu durumu şöyle ifade etmektedir:

"Okulda daha çok WhatsApp üzerinden arkadaşlarının fotoğrafını izinsiz olarak çekmek ve paylaşmak şeklinde sorunlarla karşılaşıyoruz bazı sosyal mecralar üzerinden hakaret gibi sorunlar da yaşanabiliyor"

Öğrenciler sadece okul arkadaşları tarafindan değil sosyal medya üzerinden tanıştıkları kişilerle de zaman zaman siber zorbalık davranışıyla karşı karşıya kalabiliyorlar. Rahşan bu durumu şöyle ifade etmektedir:

"Yanlış sosyal medya kullanımı öğrencilerin yanlış arkadaş edinmelerine ve özel hayatlarında sıkıntılar yaşamalarına sebep oluyor. Özel bilgilerini, örneğin okul adreslerini sosyal medyada paylaşabiliyorlar. Okul adresini paylaşan öğrenciler sosyal medya üzerinden tanıştıkları kişilerle sorun yaşadıklarında okul çıkışlarında bu kişiler tarafından sıkıştırılabiliyorlar”.

Sosyal medyada takipçi sayısı öğrenciler açısından oldukça önem taşımaktadır. Bu nedenle bazı öğrencilerin hiç tanımadıkları kişileri de takipçi listelerine ekledikleri ya da gelen takipçi davetlerini hiç düşünmeden onayladıkları görülmektedir. Candan bu durumu şu şekilde ifade etmektedir;

"Sosyal medyada takipçi sayılarının artması için öğrenciler hiç tanımadıkları kişileri de kabul edebiliyorlar bu durum onların internet üzerinden zarar görme ihtimalini artırabiliyor"

Psikolojik danışmanlar öğrencilerin (özellikle de küçük yaşlardaki öğrencilerin) evde akıllı telefon, tablet ve bilgisayar gibi teknolojik cihazlarla çok fazla vakit geçirdiklerini ve geçirilen bu vakitte genellikle kontrolsüz bir içerikle karşı karşıya kaldıklarını ifade etmişılerdir. Bu durumda özellikle küçük yaşlardaki çocuklar zaman zaman cinsel içerikli videolar ya da resimlerle karş1 karşıya kalmaktadırlar. Çocukların yaş dönemine uygun olmayan bu içerikler çocukların zarar 
görmesine ve okulda uyum ve davranış problemi göstermelerine neden olmaktadır. Mehtap bu konuda şunları ifade etmiştir:

"Özellikle cinsel içerikli videolar izleyen ya da pornografik fotoğraflara maruz kalan çocuklarda bazı davranış problemleri gözlemleyebiliyoruz. Örneğin küfür, arkadaşının özel bölgesine dokunma ya da gördüklerini arkadaşları üzerinde uygulamaya çalışmak gibi davranışları gözlemleyebiliyoruz. Aynı zamanda WhatsApp üzerinden paylaşılan özel fotoğrafların yayılması ile birlikte de ortaya olumsuz sonuçlar çıkabiliyor ki, bu durum bu yaş grubu için oldukça riskli bir davranış..."

Ergenlerin yetişkin hayatında olmak istedikleri model arayışında oldukları bilinmektedir. $\mathrm{Bu}$ noktada öğrenciler internet üzerindeki bazı karakterleri takip etmekte ve bu karakterlerin özellikleriyle özdeşim kurabilmektedirler. Bu durumu Feyza şu şekilde ifade etmektedir:

"YouTube'da fenomen olmuş çocuklara hitap eden şahıslar genellikle olumsuz örnek oluşturacak kişiler olarak karşımıza çıkıyor. Bu kişilerin çok küfürlü konuştuklarını dile getiriyorlar kendi konuşma ve davranış problemlerini onlara bağlıyorlar".

Sümeyye ise;

"Youtuber ve instagram fenomenlerinin isimleri, Kore dizileri ve Kore müzik gruplarını öğrencilerden öğreniyorum.”

ifadesi ile öğrencilerin yaşamında gerçek yaşamın dışında bir dünyada kimliklenme arayışı içinde olduklarını vurgulamıştır.

Psikolojik danışmanlar velilerin internet olgusunu anlamakta güçlük çektiklerini, internetten sıklıkla korktuklarını ancak denetim konusunda sorumluluk almaktan ise kaçındıklarını ifade etmişlerdir.

Velilerin de bu konularda ciddi endişeler içerisinde oldukları katılımcılar tarafindan ifade edilmiştir. Bazı katılımcılar velilerin endişeleri nedeniyle sık sık psikolojik danışmaları başvurduklarını ve çocuklarını korumaları için psikolojik danışmanlardan yardım istediklerini ifade etmiştir. Bu durum Gamze tarafindan şu şekilde ifade edilmiştir:

“Online oyunlarda katılımcıların sınırlandırılması ve yaş gruplarına ayrılmaması insanların kendilerini farklı şekilde göstererek özellikle küçük yaşlardaki çocuklara tacizde bulunması gibi olayların yaşandığına şahit olduk; dolayısıyla aileler endişeleniyorlar”.

Psikolojik danışmanlar öğrencilere internet konusunda yardımcı olmaya çalışsalar da zaman zaman ailelerle işbirliği yapma konusunda ciddi sorunlar yaşamaktadırlar. Bu konu hem sorunun çözülmesini güçleştirmekte, hem de çocukların ilerde sağlıklı bireyler olarak yetişmesin önünde engel olarak görülmektedir. Feyza bu konuda şunları söylemektedir:

"Üçüncü sınıfa giden ve sürekli arkadaşlarına şiddet uygulayan küfür eden bir öğrencim var. Bilgi aldığımda öğrencinin evde uzun süre telefon ve bilgisayarda şiddet içerikli oyunlar oynadığını, baba ve anne çalıştığı için evde olmadığını ve çocuğun evde geç saate kadar kontrolsüz kaldığını öğrendim. Veli ile konuşup çözüm üretmeye çalıştığımızda sürekli direnç gösteriyor ve yapıyorum dese de aslında birçok şeyi yapmıyor. Sadece günü nasıl kurtarırım çocuğu nasıl sabit bir yerde tutarım düşüncesiyle hareket ediyor"

Elvan, başka öğrenci ile yaşadığı sorunu şu şekilde ifade etmiştir: "Veliler günlük işlerini devam ettirmek, çocuklarının sorun çıkarmasını engellemek ve çocuğun ağlamasını durdurmak gibi sebeplerle çocuklarına akıllı telefon ve tabletleri rahatça veriyorlar. Bilgilendirme yapsam yapılması gereken yöntemler konusunda destek olsam dahi veliler günlük yorgunluklarına bir de çocuğu eklememek için sorumluluk almaktan uzak duruyorlar"

Bazı veliler güncel yaşamın zorlukları nedeniyle çocuklarına vakit ayırmada ve ebeveynlik rollerini yerine getirmekte zorlanmaktadırlar. Yapılan görüşmelerde velilerin psikolojik danışmanlar tarafından ortaya koyulan önerileri uygulamakta isteksiz davrandıkları görülmektedir. Habibe bu durumu şöyle ifade etmektedir: 
"Veliler bu konuda öğrenci ile çatışmaya girmekten başka bir şey yapmıyor ve çözüm konusunda ne kadar bilgilendirirsek bilgilendirelim velilerde değişim çok zor oluyor; işin büyük bir kısmı bize kalıyor. Okul mevcutları da fazla olduğu için benim de öğrencilerle detaylı olarak çalışmalar yapman çok zor oluyor".

Hümeyra ise ebeveynlik rollerine vurgu yapmaktadır:"Aileler bu konuda uyarı ve çatışmanın dışında sorunun çözümünde pasif kalıyorlar. Yapılan görüşmelerde bu konu tekrar bir ebeveynlik görevi olarak ailelere sunuluyor ancak bazı ailelerin ebeveynlik görevini yapmakta zorlandıkları ya da isteksiz davrandıkları görülmektedir"

Bazı velilerin çocuklarını internet ile ilgili davranışlarında kontrol etmekte zorlandıkları ve psikolojik danışmanlardan bu sorumluluğu paylaşmalarını istedikleri ifade edilmiştir. $\mathrm{Bu}$ durum Zeynep tarafından şu şekilde ifade edilmiştir:

“Aile gelip diyor ki, hocam bizim çocuk bizim sözümüzü dinlemiyor özellikle siz bu konuda bir şey söylerseniz sizin sözünüzü daha çok tutar ne olur ona bunları söyleyin”.

Yaş itibariyle bir anlamda internetin içine doğan şu anki öğrenciler teknolojiyi ve interneti yetişkinlere göre çok daha kolay anlamakta ve kullanmaktadırlar. Yetişkinler önceki dönemlerde birçok şeyi bilen kişi konumundayken artık internetle birlikte daha küçük yaştaki öğrenciler bilgi anlamında yetişkinlerin önüne geçmiş konumdadır. Dolayısıyla yetişkinler iyi bilmedikleri bir mecrada çocuklarına ve öğrencilerine rehberlik yapmakta zorlanmakta ve öğrenciler yetişkinleri farklı biçimde yönlendirebilmektedir. Fatma bu durumu

"Öğrenciler bilgisayar teknolojileri konusunda bizden çok daha ilerdeler. Bir öğrencim kendi adına internet ortamında yayınlanan sahte bir sınav sonuç belgesi oluşturmuştu. Bu belgede dört yılllk bir üniversiteye yerleştiği görünüyordu. Tesadüf eseri kendim ÖSYM sınav sonuç sitesine girdiğimde hiçbir programa yerleşmediğini öğrendim. Gerçek sonuca ailesini inandırmakta zorlandım çünkü öğrenci kazandığını belirttiği üniversitenin bulunduğu şehre gitmişti bile" ifadeleriyle açıklamıştır.

Psikolojik danışmanlar da internetle bağlantılı siber zorbalık, bağımlılık ve sosyal medya sorunları nedeniyle kendilerini yeterli hissetmemektedirler. Danışma esnasında öğrencilerin dilinden konuşmakta ve bahsettikleri kavramları anlamakta güçlükler yaşamaktadırlar. Bu durumu Metin şu şekilde açıklamaktadır:

"Uçsuz bucaksız bir derya olması sebebiyle internetle ilgili çok yetkin olmadığımı hissettiriyor. Özellikle oyunlar hakkında çok yetkin değilim. Öğrencilerin bahsettiği oyunları anlamakta zorlanıyorum.

Kendilerini yetkin hissetmediklerinde ise çaresizlik duygusu yaşamaktadırlar. Ali,

"Maalesef hiç yetkin hissetmiyorum, bu durumla nasıl başa çıkılmalı bununla alakalı araştırmalar yapmaya çalışıyorum fakat yeterli olmuyor dolayısıyla zorlandığım zamanlar çok oluyor".

diyerek yeterince bilgiye sahip olmadığı ve eğitime ihtiyacı olduğunu dile getirmektedir. Üniversitede internet konusunda bir dersin olmaması psikolojik danışmanların kendilerini bu anlamda donanımlı hissetmemelerine yol açmaktadır. Aslı bu konuda şunları söylemektedir:

"Bu konularda bir eğitim almadığımız için, yapabileceğimiz tek şey sadece olması gereken ve zamanını nasıl değerlendirmesi gerektiği ile ilgili yüzeysel konuşmalar ile kısıtlı”.

Buraya kadarki bölümde psikolojik danışmanların danışma sürecinde karşılaştıkları sorunlara ve yaşadıkları deneyimlere yer verilmiştir. Özetle, psikolojik danışmanların okulda sıklıkla siber zorbalık, bilgisayar oyunları ve sosyal medya kullanımı nedeniyle sorunlar yaşadıkları, bazı ailelerle işbirliği yapmakta zorlandıkları görülmüştür.

Araştırmanın diğer sorusu ise psikolojik danışmanların okulda neler yaptıklarına ilişkindir. 
Tablo 3. Psikolojik Danıșmanların Yetkin Hissetme Durumu

\begin{tabular}{|c|c|c|c|}
\hline $\begin{array}{l}\text { Tema } \\
\text { (Kategoriler) }\end{array}$ & Kodlar & $\mathbf{N}$ & $\%$ \\
\hline \multirow{11}{*}{$\begin{array}{l}\text { Psikolojik } \\
\text { Danışmanların } \\
\text { Karşılaştıkları } \\
\text { Sorunlar ve } \\
\text { Deneyimler }\end{array}$} & Sosyal Medya & & \\
\hline & Instagram & 6 & 24 \\
\hline & WhatsApp & 11 & 44 \\
\hline & Facebook & 3 & 12 \\
\hline & Youtube & 8 & 40 \\
\hline & Bilgisayar oyunları & 17 & 68 \\
\hline & Sanal zorbalık & 8 & 32 \\
\hline & Kimliklenme & & \\
\hline & Popüler youtuberlar & 6 & 24 \\
\hline & Kore dizileri & 1 & 4 \\
\hline & Instagram fenomenleri & 1 & 4 \\
\hline
\end{tabular}

Tablo 3 incelendiğinde, psikolojik danışmanların okullarda karşılaştıkları internet temalı sorunlar karşısında kendilerini \%84 oranında yetkin hissetmedikleri görülmüştür. sunulmaktadır.

Psikolojik danışmanların bu konudaki görüşlerinden alınan birebir alıntılar aşağıda

"Uçsuz bucaksız bir derya olması sebebiyle internetle ilgili çok yetkin olmadığımı hissettiriyor. Özellikle oyunlar hakkında çok yetkin değilim. Öğrencilerin bahsettiği oyunları anlamakta zorlanıyorum". (Metin)

"Maalesef hiç yetkin hissetmiyorum. Bu durumla nasıl başa çıkılmalı bununla alakalı araştırmalar yapmaya çalışıyorum fakat yeterli olmuyor. Dolayısıyla zorlandığım zamanlar çok oluyor”. (Ali)

Tablo 4. Psikolojik Danıșmanların Verdiği Hizmetler

\begin{tabular}{llll}
\hline $\begin{array}{l}\text { Tema } \\
\text { (Kategoriler) }\end{array}$ & Kodlar & $\mathbf{n}$ & $\mathbf{\%}$ \\
\hline & Ö̆ğenci seminerleri & 9 & 36 \\
Psikolojik & Veli seminerleri & 13 & 52 \\
Danışmanların & Broşür hazırlama & 2 & 8 \\
Verdiği & Bireysel psikolojik danışmanlık & 8 & 32 \\
Hizmetler & Grup rehberliği & 1 & 4 \\
\hline
\end{tabular}

Tablo 4 incelendiğinde, psikolojik danışmanların okullarda internetle bağlantılı sorunları çözüm getirebilmek amacıyla en fazla $\% 52$ oranında velilere yönelik seminer yaptıkları görülmüştür. \%36 oranında ise öğrenci semineri yaptıklarını bildirmişlerdir.

"İlk oyun karakterlerinden ve oyun videolarından bahsederlerken nelerden bahsettiklerini anlamamıştım ve kendimi yetersiz hissettim. Char, Klan vs. terimlerin neyi ifade ettiğini anlayamamıştım. 
Okul Psikolojik Danışmanlarının Gözünden Sosyal Medya Siber Zorbalık ve Bilgisayar... 1361

Özellikle somutlaştırma ve örneklendirme açısından hizmet içi eğitim gereklidir diye düşünüyorum". (Hüseyin)

"Bu konularda bir eğitim almadığımız için, yapabileceğimiz tek şey sadece olması gereken ve zamanını nasıl değerlendirmesi gerektiği ile ilgili yüzeysel konuşmalar ile kısıtlı”. (Zeynep)

Tablo 5. Psikolojik Danışmanların Hizmet içi Eğitime İhtiyaç Duydukları Konular

\begin{tabular}{llcc}
\hline $\begin{array}{l}\text { Tema } \\
\text { (Kategoriler) }\end{array}$ & Kodlar & N & \% \\
\hline & Sosyal medya & 12 & 48 \\
& Oyunlar & 10 & 40 \\
Hizmet içi & Siber zorbalık & 6 & 24 \\
$\begin{array}{l}\text { Eğitime } \\
\text { İhtiyaç }\end{array}$ & Aile bilgilendirme & 3 & 12 \\
Duyulan & Kodlama & 1 & 4 \\
konular & Özel hayat ve mahremiyet & 1 & 4 \\
& Sosyal medyada öğretmen öğrenci ilişkisi & 1 & 4 \\
\hline
\end{tabular}

Tablo 5 incelendiğinde, psikolojik danışmanların internetle ilgili konularda çalışırken en fazla $\% 48$ oranında sosyal medya hakkında hizmet içi eğitime ihtiyaç hissettikleri belirlenmiştir. $\% 40$ oranında ise bilgisayar oyunları hakkında çalışırken kendilerini yeterli hissetmediklerini belirtmişlerdir. Psikolojik danışmanların görüşlerinden alınan alıntılar aşağıda sunulmaktadır. (Candan)

"Özellikle; sosyal medya bağımlılığı ile ilgili bir eğitimin çok faydalı olacağını düşünüyorum”.

"Teknoloji ve oyun bağımlılığı olabilir. Oynanan oyunların isimlerinin de yer aldığı, türü, süresi, bağımlılığa giden yol onlara onların dilinden anlatılabilir”. (Mehtap)

Tablo 6. Psikolojik Danışanların Hizmet içi Eğitimden beklentilerine iliş̧kin görüşleri

\begin{tabular}{llll}
$\begin{array}{l}\text { Tema } \\
\text { (Kategoriler) }\end{array}$ & Kodlar & $\mathbf{n}$ & $\mathbf{\%}$ \\
\hline & Doyurucu öneriler verilmeli & 3 & 12 \\
& Oyunlar hakkında bilgilendirme & 2 & 8 \\
& Uygulamaya dönük olması & 12 & 48 \\
\multirow{3}{*}{$\begin{array}{l}\text { Hizmitimet içi } \\
\text { beklentiler }\end{array}$} & İşlevsel olması & 2 & 8 \\
\cline { 2 - 4 } & Aile ile işbirliğini kolaylaştıracak öneriler & 3 & 12 \\
\cline { 2 - 4 } & Vaka örnekleri & 3 & 12 \\
\cline { 2 - 4 } & Teknolojiyle barışı eğitimler & 4 & 16 \\
\hline
\end{tabular}

Tablo 6 incelendiğinde, psikolojik danışmanların internet konusunda hizmet içi eğitimden beklentileri okullarda çalıştıkları süreçte kendilerini yetersiz hissettikleri durumlar en fazla $\% 48$ oranında uygulamaya yönelik önerilerin verileceği eğitimler olduğu görülmüştür. \%16 oranında ise 
teknolojiyle barışık eğitimlerin verilmesini istediklerini bildirmişlerdir. Psikolojik danışmanların görüşlerinden alınan alıntılar aşağıda sunulmaktadır.

"Eğitimlerin anlatım düzeyinde değil de okul ortamında ya da sınıf ortamında yaşanan sorunlara bire bir somut örneklerle ve somut çalışma örnekleriyle katkı sağlanmasını istiyorum. Yani kısacası uygulamaya koyabileceğim, gerçekçi ve uygulanabilir bilgilerin verildiği eğitimler olsun istiyorum. (Zeynep)

“Özellikle somutlaştırma ve örneklendirme açısından hizmet içi eğitim gereklidir diye düşünüyorum”. (Hüseyin)

\section{Tartışma Sonuç ve Öneriler}

Psikolojik danışmanların okulda karşılaştıkları internet temalı sorunların incelendiği bu çalışmada psikolojik danışmanların bilgisayar oyunları, sosyal medya bağımlılı̆̆ 1 ve siber zorbalık konularıyla sıklıkla karşılaştıkları, farklı tarzlardaki oyunları öğrenmek zorunda kaldıkları belirlenmiştir. Psikolojik danışmanların okulda ağırlıklı olarak öğrenci ve veli bilgilendirme seminerleri yaptıkları, grup rehberliği programlarının ise nadir olarak yapıldığı belirlenmiştir. Aynı zamanda psikolojik danışmanların karşılaştıkları internet temalı sorunları çözmek içinkendilerini yetkin hissetmedikleri, sosyal medya, bilgisayar oyunları ve siber zorbalık konularında hizmet içi eğitime ihtiyaç duydukları, ancak yapılacak eğitimlerin uygulamaya dönük ve teknolojiyle barışık eğitimler olması gerektiğini düşündükleri belirlenmiştir. Yapılan literatür taramasında internetle ilişkili daha çok çocuk ve ergenler üzerine yapılan çalışmalara rastlanmıştır. Bu bağlamda bu araştırma psikolojik danışmanların perspektifinden yapılması açısından önemlidir.

Psikolojik danışmanların okulda en sık karşılaştıkları sorunlar; bilgisayar oyunları, WhatsApp ve sanal zorbalık üzerinedir. Öğrenciler arasında bilgisayar oyunları oynamak popüler bir etkinliktir. Dolayısıyla bu sonucun beklendiği söylenebilir. Yeşilyurt (2014) tarafından yapılan çalışmada Lise grubunda öğrenciler arasında erkeklerin \%79,6'sının, kızların \%45,1'inin okul arkadaşlarıyla oyunlar ile ilgili sohbet ettikleri bulunmuştur. Genel olarak oyun bağımlılığı yaygınlığının \%7,9 ile \%3 arasında olduğu bilinmektedir (Desai vd. 2010; Peker vd. 2010; Van Roij vd. 2011). Ancak bilgisayar oyunlarıyla ilgili yaşanan sorunlar sadece bağımlılıkla ilişkili olmayabilir. Dolayısıyla bu bulgu oyun bağımlılığının yaygınlık oranlarıyla beklenmeyen bir sonuç gibi görülebilir. Ancak Yeşilyurt'un çalışmasıyla uyumlu görülmektedir.

Bilgisayar oyunlarının dışında psikolojik danışmanların WhatsApp ve sanal zorbalık konularıyla sıklıkla karşılaştıkları bulunmuştur. WhatsApp ve sanal zorbalık konusu birlikte ele alınması gereken konulardır. Çünkü psikolojik danışmanların WhatsApp ile ilgili anlattıkları sorunların sanal anlamda zorbalık davranışlarıyla ilişkili olduğu görülmüştür. Bu bulgu sanal zorbalığın yaygınlığıyla ilgili yapılan çalışmalarla uyumludur. Çalışmalarda sanal zorbalığın yaygınlığı ilköğretim öğrencilerinde \%18,6 (Ayas ve Horzum 2011), İlköğretim ikinci kademede \%32,6 (Aydoğan, Dilmaç ve Deniz, 2009), lise grubunda ise \%17,4 olarak bulunmuştur. ErdurBaker ve Kavsut (2007) tarafından yapılan çalışmada sanal kurban oranının ise \%30'a ulaştığı bulunmuştur. Siber zorbalıkla ilgili yapılan çalışmalarda farklı yaygınlık oranları bulunmuş olsa da bu çalışmalar siber zorbalık davranışının öğrenciler arasında yaygın bir davranış olduğunu düşündürmektedir. Dolayısıyla psikolojik danışmanların sıklıkla WhatsApp ve sanal zorbalık davranışlarıyla karşılaş̧maları sanal zorbalığın öğrenciler arasında yaygın bir davranış olarak görüldügünü anlatan bulgularla uyumludur.

Araştırmada psikolojik danışmanların ağırlıklı olarak internetle ilgili veli seminerleri düzenledikleri bulunmuştur. Okul psikolojik danışmanı, etkinliklerini yürütürken zamanını ve enerjisini etkin bir şekilde kullanması gerekir. Doğan'a (2001) göre bunun temel koşulu büyük gruplarla, grup rehberliği biçiminde çalışmaktır. Ancak yapılan bu çalışmanın bulgularına göre; psikolojik danışmanlar nadiren grup rehberliği çalışmaları yapmaktadırlar.

Araştırmada psikolojik danışmanların internetle ilgili sorunlarda kendilerini yeterli hissetmedikleri ve hizmet içi eğitime ihtiyaç duydukları bulunmuştur. Psikolojik danışmanlar 
sosyal medya ve bilgisayar oyunları konusunda hizmet içi eğitime ihtiyaç duymaktadırlar. Hizmet içi eğitimde kuramsal bilgilerden çok uygulamaya dönük eğitimlere ihtiyaç duydukları saptanmıştır.

Bu araştırmada bazı sınırlılıklar bulunmaktadır. Öncelikle çalışma görüşmelerde kullanılan görüşme soruları ile sınırlıdır. Daha sonraki çalışmalarda sanal zorbalık ve oyun bağımlılığı konularında daha ayrıntılı ve kapsamlı hibrit çalışmalar planlanabilir. Ayrıca katılımeı sayısının nicel çalışmalara göre düşük olması çalışmanın bir diğer kısıtlılığı olarak düşünülebilir. Diğer taraftan, sorunların tarafı olan öğrenci ve velilerin de dâhil edilmesi bu araştırmayı daha değerli k1labilirdi.

Milli Eğitim Bakanlığı yetkilileri psikolojik danışmanların internetle ilgili konularda bilgi ihtiyacını karşılamaya yönelik özellikle sosyal medya kullanımı ve bilgisayar oyunları konularında hizmet içi eğitim planları hazırlamaları ve bu eğitimlerin içeriğinin mümkün olduğunca uygulamaya yönelik çalışmalar olması gerekmektedir. Psikolojik danışmanların zamanlarını daha etkili kullanmaları açısından öğrencilere yönelik grup rehberliği etkinlikleri yapmaları faydalı olacaktır.

\section{Kaynakça}

Arıcak, O. T. (2009). Üniversite öğrencilerindeki siber zorbalık davranışlarının bir yordayıcısı olarak psikiyatrik belirtiler. Eurasian Journal of Educational Research, 34, 167-184.

Arslan, N. Psikolojik Danışmanlarda Tükenmişlik: Nitel Araştırma Örneği. OPUS Uluslararası Toplum Araştırmaları Dergisi, 8(15), 7-7. https://doi.org/10.26466/opus.419320

Ayas, T. (2012). Lise öğrencilerinin internet ve bilgisayar oyun bağımlılık düzeylerinin utangaçlıkla ilişkisi. Kuram ve Uygulamada Eğitim Bilimleri, 12(2), 627-636.

Ayas, T., \& Horzum, M. B. (2012). İlköğretim öğrencilerinin sanal zorba ve mağdur olma durumu. Illköğretim Online, 11(2).

Aydoğan, D., Dilmaç, B., \& Deniz, E. (2009). İlköğretim öğrencilerinde sosyal destek ve siber zorbalığın incelenmesi. 18. Ulusal Eğitim Bilimleri Kurultayı'nda sunulmuş sözlü bildiri. Ege Üniversitesi, İzmir. https://doi.org/10.17860/mersinefd.282384

Ceyhan, E. (2008). Ergen ruh sağlığı açısından bir risk faktörü: İnternet bağımlılığı. Çocuk ve Gençlik Ruh Sağlı̆̆l Dergisi, 15(2), 109-116. https://doi.org/10.14527/9786053644590

Çetinkaya, M. (2013). Illköğretim öğrencilerinde internet bă̆ımlılı̆̆ının incelenmesi. Yayınlanmamış Doktora Tezi . DEÜ Eğitim Bilimleri Enstitüsü.

Desai, R. A., Krishnan-Sarin, S., Cavallo, D., \& Potenza, M. N. (2010). "Video-Gaming Among High School Students: Health Correlates, Gender Differences, And Problematic Gaming". Pediatrics,126 (6), e1414-e1424 https://doi.org/10.1542/peds.2009-2706

Doğan, A. (2013). Internet bağımlılı̆̆ı yaygınlı̆̆ı. Yayınlanmamış Doktora Tezi. DEÜ Eğitim Bilimleri Enstitüsü.

Erdur-Baker, Ö., \& Kavşut, F. (2007). Akran Zorbalığının Yeni Yüzü: Siber Zorbalık. Eurasian Journal of Educational Research (EJER), (27).

Gökçearslan, Ş., \& Günbatar, M. S. (2012). Ortaöğrenim öğrencilerinde internet bağımlılığı. Eğitim Teknolojisi Kuram ve Uygulama, 2(2), 10-24.

Hamamc1, Z. (2007). Gelişen Psikolojik Danışma ve Rehberlik (Meslekleşme sürecinde ilerlemeler). Nobel Yayın Dağıtım. 
Horzum, M. B. (2011). İlköğretim öğrencilerinin bilgisayar oyunu bağımlılık düzeylerinin çeşitli değişkenlere göre incelenmesi. Eğitim ve Bilim, 36(159). https://doi.org/10.17680/erciyesiletisim.379886

Kaya, A. \& Çivitçi, A. (2004). Okul Psikolojik Danışma ve Rehberlik Programlarının Geliştirilmesi (Ed: Gürhan Can). Psikolojik Danışma ve Rehberlik (ss. 227-254). Pegem Yayınc1lık. https://doi.org/10.14527/9789756802656.08

Kayri, M., \& Gunuc, S. (2010). An Analysis of Some Variables Affecting the Internet Dependency Level of Turkish Adolescents by Using Decision Tree Methods. Educational Sciences: Theory and Practice, 10(4), 2487-2500.

Keklik, İ. (2016). Psikolojik danışma alanının hak savunuculuğu bağlamında birey ötesi sorumlulukları. Türk Psikolojik Danışma ve Rehberlik Dergisi, 4(33). https://doi.org/10.14527/9786053184614.09

Korkut, F. (2003b). Rehberlikte önleme hizmetleri. Selçuk Üniversitesi Sosyal Bilimler Enstitüsü Dergisi, 9, 441-452.

Korkut-Owen, F. \& Owen, D. W. (2008). Okul Psikolojik Danışmanlarının Rol ve İşlevleri: Yöneticiler ve Psikolojik Danışmanların Görüşleri. Ankara Üniversitesi Ĕgitim Bilimleri Fakültesi Dergisi, 41(1), 204-218. https://doi.org/10.1501/egifak 0000000199

Özyürek, R. (2009). Okullarda psikolojik danışma ve rehberlik uygulamaları ve öğrencilere sağlanan süpervizyon olanakları: Ulusal bir tarama çalışması. Türk Psikolojik Danışma ve Rehberlik Dergisi, 4(32), 54-63 https://doi.org/10.14527/9789756802656.03

Öztabak, M. Ü. Problemli İnternet Kullanımı Olan Ergenlerin İnternet Kullanımına İlişkin Duygu ve Görüşlerinin İncelenmesi. OPUS Uluslararası Toplum Araştırmaları Dergisi, 8(15), 1111. https://doi.org/10.26466/opus.419667

Peker, A., \& Eroğlu, Y. (2010). Erkek öğrencilerde siber zorba ve kurban olmanın yordayıcıs1 olarak internet bağımlılı̆̆ı. Sünbül, AM ve Şahin, İ.(Eds.), 4, 862-867.

Savaş, A. C., \& Hamamc1, Z. (2010). Okullarda rehberlik hizmetlerinin internet üzerinden yürütülmesine ilişkin veli, öğrenci ve psikolojik danışmanların görüşlerinin incelenmesi. Pamukkale Üniversitesi Ë̆itim Fakültesi Dergisi, 27(27), 147-158. https://doi.org/10.17556/erziefd.405142

Sağlık Bakanlığı (2011). "Sağlık Bakanlığı Ulusal Ruh Sağlığı Eylem Planı”. [Online]: http://www.saglik.gov.tr/TR/dosya/173168/h/ulusal-ruh-sagligi-eylemplani.(2019, May1s 15) https://doi.org/10.1501/kriz 0000000204

Seğmenli, S. (2001). Rehber öğretmenlerin tükenmişlik düzeylerinin incelenmesi. Yayınlanmamış Yüksek Lisans Tezi. Hacettepe Üniversitesi, Sosyal Bilimler Enstitüsü. https://doi.org/10.18506/anemon.520901

Taş, İ.(2018) Ergenlerde İnternet Bağımlılı̆̆ı ve Psikolojik Belirtilerin Çeşitli Değişkenler Açısından İncelenmesi. Anemon Muş Alparslan Üniversitesi Sosyal Bilimler Dergisi, 6(1), 31-41. https://doi.org/10.18506/anemon.310973

Türkiye İstatistik Kurumu. Hanehalkı Bilişim Teknolojileri Kullanım Araştırması, (2016, Mart16) . TUIK Haber Bülteni Say1 21779. http://www.tuik.gov.tr/PreHaberBultenleri.do?id=21779 https://doi.org/10.18074/cnuiibf.395

American Psychiatric Association, Asparouhouv, T., Muthén, B. O., Beidel, D., Turner, S., Young, B., ... \& Pallanti, S. Van Rooij, AJ, Schoenmakers, TM, Vermulst, AA, Van Den Eijnden, RJJM, \& Van De Mheen, D.(2011). Online video game addiction: identification of 
Okul Psikolojik Danışmanlarının Gözünden Sosyal Medya Siber Zorbalık ve Bilgisayar... 1365

addicted adolescent gamers. Addiction, 106(1), 205-212. https://doi.org/10.1111/j.1360$\underline{0443.2010 .03104 . \mathrm{x}}$

Yaman, E.,\& Peker, A. (2012). Ergenlerin siber zorbalık ve siber mağduriyete ilişkin algıları. Gaziantep University Journal of Social Sciences, 11(3), 819-833.

Yeşilyurt, F. (2014). Ergenlerin çevrim içi oyunlardaki deneyimleri ve oyuna ilişkin tutumlarının incelenmesi. Doktora Tezi, İstanbul Üniversitesi, Eğitim Bilimleri Enstitüsü.

İnfografik (2019, mayıs 10) https://www.aa.com.tr/tr/info/infografik/11481 